\title{
Brand personality creation through advertising
}

Citation for published version (APA):

Ouwersloot, J., \& Tudorica, A. (2001). Brand personality creation through advertising. METEOR, Maastricht University School of Business and Economics. METEOR Research Memorandum No. 039 https://doi.org/10.26481/umamet.2001039

Document status and date:

Published: 01/01/2001

DOI:

10.26481/umamet.2001039

Document Version:

Publisher's PDF, also known as Version of record

\section{Please check the document version of this publication:}

- A submitted manuscript is the version of the article upon submission and before peer-review. There can be important differences between the submitted version and the official published version of record.

People interested in the research are advised to contact the author for the final version of the publication, or visit the DOI to the publisher's website.

- The final author version and the galley proof are versions of the publication after peer review.

- The final published version features the final layout of the paper including the volume, issue and page numbers.

Link to publication

\footnotetext{
General rights rights.

- You may freely distribute the URL identifying the publication in the public portal. please follow below link for the End User Agreement:

www.umlib.nl/taverne-license

Take down policy

If you believe that this document breaches copyright please contact us at:

repository@maastrichtuniversity.nl

providing details and we will investigate your claim.
}

Copyright and moral rights for the publications made accessible in the public portal are retained by the authors and/or other copyright owners and it is a condition of accessing publications that users recognise and abide by the legal requirements associated with these

- Users may download and print one copy of any publication from the public portal for the purpose of private study or research.

- You may not further distribute the material or use it for any profit-making activity or commercial gain

If the publication is distributed under the terms of Article $25 \mathrm{fa}$ of the Dutch Copyright Act, indicated by the "Taverne" license above, 


\section{Brand Personality Creation through Advertising}

Hans Ouwersloot

Anamaria Tudorica

MAXX WORKING PAPER SERIES

Maastricht Academic Center

for research in Services

Maxx 


\section{Brand Personality Creation through Advertising}

\section{$\underline{\text { Abstract }}$}

Brand Personality is one of the core dimensions of brand equity. Brand personality refers to the emotional side of a brand image. It is created by all experiences of consumers with a brand, but advertising plays a dominant role in personality creation.

In this paper we explore the mechanism that builds brand personality with the help of advertising. We integrate advertising models with the theory of brand personality. Our integrated framework leads to a number of propositions that set an agenda in this field. In building our framework we incorporate theories from the fields of marketing (brand equity and advertising), communication science and psychology (personality). 


\section{Introduction}

Brand personality is an attractive and appealing concept in the marketing of today. It is one of the core dimensions of the brand identity (D. Aaker, 1996) and perhaps the one closest to the consumers. The personality idea responds to the tendency in contemporary society to value personal relationships. It also refers to the idea that relationships are important in social life. In terms of Maslow's hierarchy of needs, it tries to lift products to higher levels of need satisfaction, like belongingness and love and esteem.

Brand personalities are created in different ways and with different tools. However, the creation always involves active communications on the side of the firm: the personality has to be disseminated to be alive. Advertising is heavily used in this process of personality creation. This follows logically from the fact that personalities are particularly useful for the creation of brand associations. Brand associations influence the' evaluation of alternatives' stage in basic consumer buying behavior models. In this stage, and for these goals, advertising is considered to be the most effective communication tools (Brassington \& Pettitt, 2000).

Perhaps the most visible and best known way of personality creations is by means of celebrity endorsers. Public heroes, sports people (Michael Jordan), pop stars (Tina Turner) and movie stars (Bruce Willis) is particular, are hired to lend their personality to a brand but this practice goes back to at least for a century (Erdogan \& Baker, 2000) ${ }^{1}$. Redenbach (2000) noted that the practice is still growing in popularity today.

Yet, basically all advertising influences the brand personality, not only when an endorser is used. In this paper we focus on this process of personality creation in a broad sense. In particular we discuss how advertising is used to create brand personality. To the end we integrate a general model of advertising with a model of brand personality creation. Based on that model we derive a number of propositions that are open to research. But we first present a thorough analysis of the role of brand personality in the creation of brand equity, thereby linking our topic to one of general and increasing importance.

\footnotetext{
${ }^{1}$ A web search provided examples from the 1950's, including an actor called Reagan, promoting antiseptic hair tonic (http://www.adh.bton.ac.uk/schoolofdesign/MA.COURSELBC02.html). Erdogan and Baker spot Queen Victoria as one of the first celebrity endorsers.
} 


\section{Brand Equity}

The concept of brand equity is one of the most popular and important marketing concepts of today. Despite its popularity it is not unequivocally defined. First there is the distinction between the financial-economic perspective and the customer-based view. The financialeconomic view sees brand equity as the (financial) worth of brands, the brand as a liability on the balance sheet. The customer-based view sees brand equity as the differential effect of a brand on consumer behavior (Keller, 1998). In this paper we will adopt and elaborate on the customer-based view.

It seems pretty obvious that the customer-based and financial-economic views on brand equity are closely related. Figure 1 depicts this relationship. Customer-based brand equity, defined as a differential effect, potentially leads to some form of consumer response. This consumer response may be either behavioral, or attitudinal, but this response is a necessary prerequisite to attach (monetary) value to a brand. The other way round, we also argue that customer-based brand equity can only be meaningfully defined when the differential effect leads to some form of consumer response.

There is also a link from the consumer response to the customer-based brand equity and from the FEBE to the CBBE. The first link merely reflects the idea that the consumer response may lead to an enhanced differential effect. The second link suggests that the very presence of FEBE leads to a differential effect. Both links will become clear when we discuss the concept of differential effect in some more detail.

\section{Figure 1: Customer-based and financial brand equity}

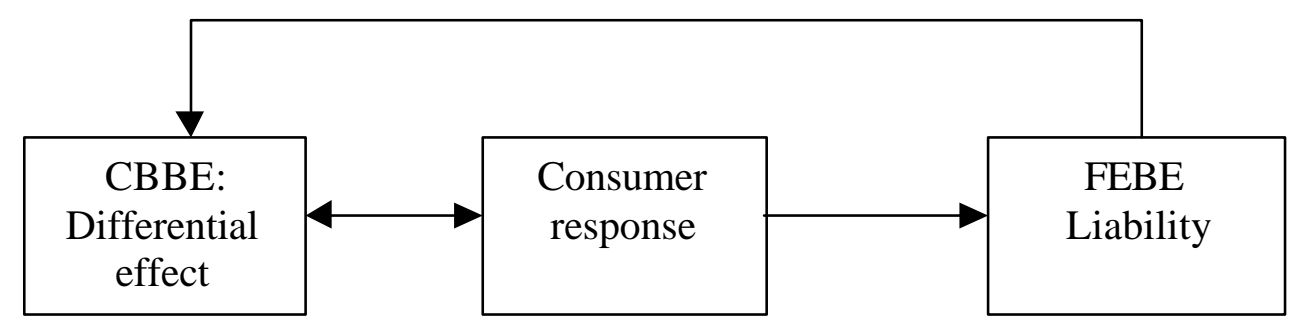

Keller (1998) discussed many definitions and views on CBBE and found that there is no agreement on the concept, except for the notion that all definitions one way or the other refer to a form of differential effect. This differential effect can be described as the difference 
between a branded product and an identical unbranded product, as experienced by the customer.

Although this definition looks conceptually sound, it must be handled carefully. "An identical unbranded product" is a hypothetical construct, unrealistic in most market places. That makes the concept vulnerable to manipulation. To prevent that, we propose to define "an identical unbranded product" as a product that has a zero (0) score in any dimension in which the brand equity is defined. Moreover, in other dimensions, e.g. product features, the unbranded product is an exact copy of the branded product discussed.

While there seems to be (implicit) consensus on the differential effect idea in the CBBE concept, there is large (and explicit) disagreement on the dimensions of the CBBE. Keller (1998) holds the most restrictive view. According to him, CBBE only exists in brand awareness and brand image; all other effects are derived from these two. David Aaker (1991) adopts a much broader view. His CBBE dimensions are: Brand loyalty, brand awareness, perceived quality, brand associations, and other proprietary brand assets. Kapferer (1997) also extends Keller's approach by defining brands assets (his term for CBBE) to be: Brand awareness, brand image, perceived quality, evocations, and familiarity and liking.

To shed some light on the controversy we propose to relate the brand equity issue to a simple model of consumer behavior. Recall that we are discussing customer-based brand equity, and that we have argued that response in the form of behavior or attitudes is necessarily linked to the whole idea of brand equity. Hence a link to a consumer behavior model is natural. Figure 2 shows an elementary, textbook consumer behavior model (Kotler \& Armstrong 2001; Dibb et al. 2001; Perreault \& McCarthy, 1999) and introduces our view on the CBBE, or differential effect concept. Indeed, in every stage of this consumer behavior model a differential effect of brands can be identified.

Figure 2: Customer-based brand equity and the consumer buying behavior model

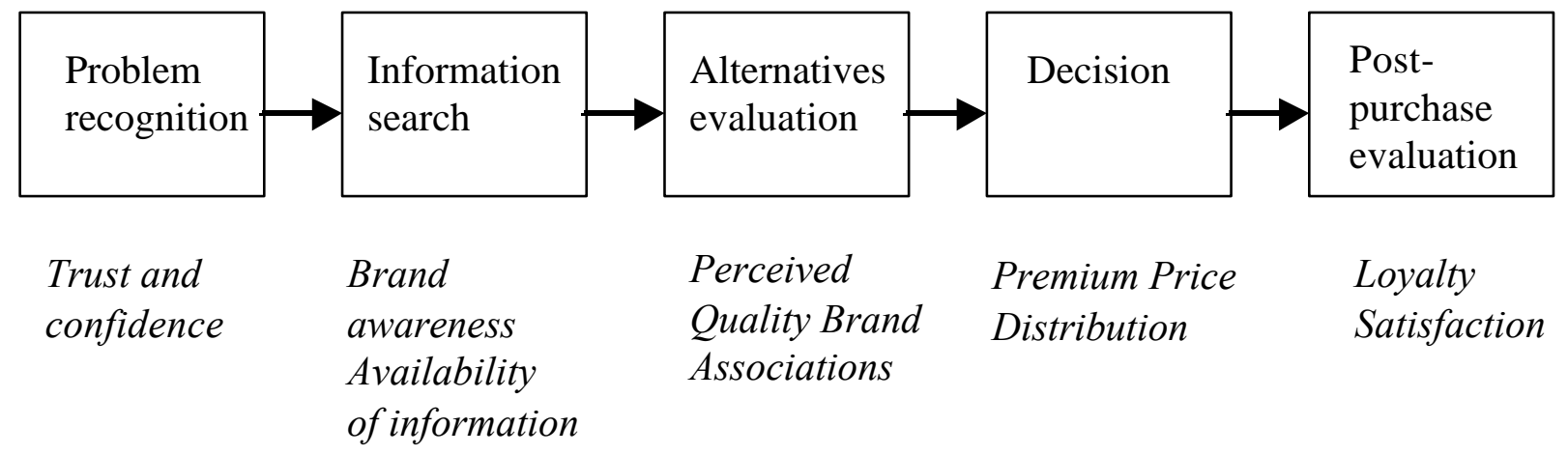


The problem recognition stage seems to be an autonomous process, and in many cases this is true. There are instances however, in which the marketers "create" the problems of the consumers, in particular in the case of innovations. Often innovations address needs or wants consumers were only latently aware of, and one of the goals when bringing product innovations to the market is to make consumers aware of the fact that those new products indeed address a thus far unrecognized need. Brands can help consumers accepting the idea that they need the new product, by the trust and confidence consumers have. 'When you say I need it, I believe you'. Microsoft is making heavy use of this mechanism with its continuous stream of updates and new versions of its software. Every new product is sold with promises of new features and capabilities most PC-users were not aware of that they were missing.

In the information search stage, the main goal of the consumer is to define the alternatives that may solve the problem and collect information about those alternatives. This is where Keller, D. Aaker, Kapferer and others start: brand awareness. Consumers should be aware of the fact that the particular brand is indeed a candidate to solve the problem and the easier the consumer recalls the brand, the greater the brand equity. An additional aspect is availability. An extra terrestrial creature landing on earth thirsty will most likely think of drinking a Coke, simply because the chances are greatest it comes across a billboard of that brand first. This availability hence refers to the pervasiveness of disseminated information.

Next, the consumer starts to evaluate the alternatives. This evaluation takes place at all levels of the product: the core level and higher levels in particular. When assessing the core level, the concept of perceived quality seems relevant. Quality can be defined as the extent to which the product is able to fulfill the needs of the consumer and is therefore crucial in the evaluation of the alternatives. Next to that, alternatives will all carry lots of associations, that may be appealing or not. In evaluating an alternative these associations can be as important as the perceived quality assessment, in particular for certain types of products, e.g. high involvement products on the one hand, or bulk goods on the other hand, where there is little differentiation in quality cues.

In the decision stage the price of a branded product, compared to the price of an identical unbranded product, is seen as one of the most concrete manifestations of CBBE, also the one that makes the strongest link to FEBE. We agree with Keller that the premium price is more of a consequence of CBBE, than that it forms the CBBE in its own right. However, adopting a slightly different approach makes clear that price premium is indeed part of the CBBE. This approach implies that all information as evaluated in the previous stage leads to a reservation price: the price a consumer is willing to pay for a product. In this reservation price, we can 
clearly see the differential effect that defines CBBE. A branded product will typically have a higher reservation price than the identical unbranded product. A consumer will compare his reservation price with the market price. When the reservation price is below the market price, the consumer will be willing buy the product, otherwise he will not. When the evaluation more than one alternative leads to a positive difference between reservation price and market price, the alternative with the largest difference will be selected. So we define the price premium as the difference in reservations price of the branded and the unbranded product. This approach to price premium is independent of the actual price charged in the market. The degree to which the company tries to make money out of this price premium based on reservation prices builds a direct link between the CBBE and FEBE, thereby leaving both concepts their distinct roles.

A second aspect of $\mathrm{CBBE}$ that relates to the decision stage is the physical availability of the product. Strong brands tend to have better access to distribution channels and consequently, when the decision is in favor of the branded product, the chances that the product is actually purchased as well are bigger (D. Aaker, 1991).

Finally, in the post-purchase evaluation stage, brands may have a positive impact on satisfaction and loyalty. Satisfaction is an attitudinal aspect. Satisfaction is defined as a measure of the extent to which the expectations have been fulfilled or exceeded. Hence, when discussing satisfaction it has to be recognized that the brand as such may already have led to higher expectations, cf. the perceived quality discussion. The satisfaction issue is indeed about exceeding these prior expectations. When the expectation for a branded product was 5 on some scale for some aspect, and the expectation for the identical unbranded product was 3, and furthermore, the ex-post evaluations of this item were 6 and 4 respectively, there is no differential effect of the brand: for both products the ex-post evaluations exceed the expectations with 1 point. Consequently both have the same satisfaction score.

Loyalty is the behavioral effect in the post-purchase evaluation stage. Like the price premium it is very closely related to FEBE. It is therefore that Keller heavily criticizes the use of loyalty as a CBBE dimension. His main argument is that repeat purchases, the operational measure of loyalty, are not necessarily driven by a loyalty notion. Repeat purchases out of habit or because of limited availability should be distinguished from repeat purchasing out of loyalty. However, the issue of availability is taken care of by the definition of the identical unbranded product. It is logical to include availability in defining an identical product. The "habit" argument is pointless. We think it is fundamental in the discussion of CBBE that brands achieve to build a habitual buying by their customers. Isn't it the best manifestations of 
brand equity when customers, standing in front of dozens of identical alternatives, pick yours without even thinking of the others?

In the remainder of this paper, we concentrate on one aspect of brand image, brand personality. As we have argued in our introduction, brand personality is both an important and appealing issue in CBBE, and it is relatively under-researched. Both are good reasons to put brand personality on top of the research agenda and as a kick-off, we will discuss in considerably detail how personality is created and what it can do to a brand and we will define a number of concrete points in the form of propositions that are open to discussion and research.

\section{Brand image}

There are different views and different definitions of brand image, which differ in their level of abstraction by how elaborated the image is built in the minds of the consumer. Concordant to the associative network memory model, the brand image is the associative brand network held in the minds of consumers (Poiesz, 1989). Thus, brand associations held in consumers' memory reflect perceptions about the brand, and the meaning of the brand for consumers.

Just like definitions, there are also different brand building image theories. Some of these theories include only the associations related to the product (Keller, 1998), while others also encompass associations related to the company (Biel, 1993), the country of origin (Holzhauer, 1991), and the image of the user (Biel, 1993).

David Aaker (1996) has developed the brand identity system, a framework for brand evaluation. According to David Aaker (1996) when creating a brand identity, the firm should consider four dimensions of brand identity: the brand as a product, an organization, a person, and a symbol. The brand identity created by the firm is communicated to consumers, who then interpret it as the brand image. Based on different brand image theories we developed a framework that in our opinion represents a good foundation for the creation of brand image in the minds of consumers. This framework is represented in figure 3. 


\section{Figure 3: The brand image}

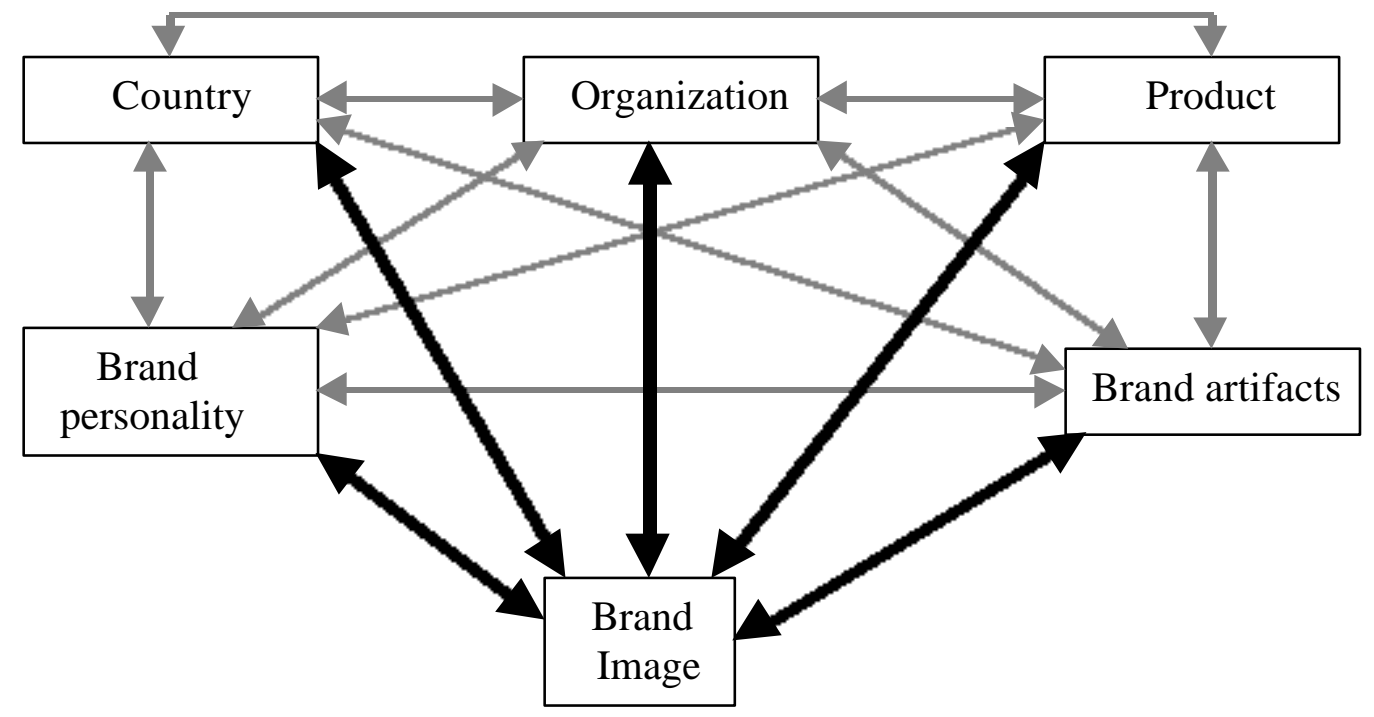

Brand image is built by associations about the organization behind the brand, the product, the country of origin, the brand personality, and the brand artifacts. These associations do not only influence the creation of the brand image; they also influence each other. In other words, there is a dual relationship between the brand image elements, and between the elements and the brand image A positive brand image occurs when these associations are strong, favorable, and unique in the minds of the consumers (Keller, 1998).

Associations related to the organization are related to the attributes of the company (e.g. level of technology, leadership style) as well as the history of the company. Product associations include the product-related attributes as well as the product scope (D. Aaker, 1996). Associations involving the country of origin, for example the level of technology in the country and the culture, also influence the brand image. With brand artifacts we refer to the typical user and usage imagery, and also to the visual imagery of the brand e.g. symbols. The brand artifacts associations are most of the time created by consumers with the help of promotional tools.

Unlike the other brand image dimensions, brand personality provides the brand with more depth, with a 'soul' that is crucial for the brand image. Brand personality can be the singleone association that is used by consumers to differentiate between products, for example markets where products are highly undifferentiated like coffee. Based on this differentiation, consumers can respond to this knowledge accordingly. Thus brand personality is a factor that influences the creation of brand equity. 


\section{Human personality and brand personality}

Keller (1998) states that “ brand personality reflects how people feel about a brand, rather than what they think the brand is or does" (p.97). The symbolic use of brands is possible because consumers often give brands human personalities (J. Aaker, 1997). Consumers perceive the brand on dimensions that typically capture a person's personality, and extend that to the domain of brands. The dimensions of brand personality are defined by extending the dimensions of human personality to the domain of brands.

One way to conceptualize and measure human personality is the trait approach, which states that personality is a set of traits (Anderson \& Rubin, 1986). A trait is defined as "any distinguishable, relatively enduring way in which one individual differs from others" (Guilford, 1973, p.23). Human personality traits are determined by multi-dimensional factors like the individual's behavior, appearance, attitude and beliefs, and demographic characteristics. Based on the trait theory, researchers have concluded that there are five stable personality dimensions, also called the 'Big Five' human personality dimensions (Batra, Lehmann \& Singh, 1993). The 'Big Five' human personality dimensions are Extraversion/introversion, Agreeableness, Consciousness, Emotional stability, and Culture.

Based on these human personality dimensions, Jennifer Aaker (1997) identifies the new ' Big Five' dimensions related to brands. These are Sincerity, Excitement, Competence, Sophistication, and Ruggedness.

The brand personality dimensions correspond to three of the 'Big Five' human personality dimensions (J. Aaker, 1997). Agreeableness and Sincerity both capture the idea of warmth and acceptance. Extraversion and Excitement both include the notions of sociability, energy, and activity, while Consciousness and Competence both connote responsibility, dependability, and security. The other two brand personality dimensions differ from any of the 'Big Five' of human personality. According to Jennifer Aaker (1997), this pattern suggests these brand personality dimensions might operate in different ways or influence consumer preference for different reasons. Whereas Sincerity, Excitement, and Competence represent an innate part of human personality, Sophistication and Ruggedness tap dimensions that individuals desire but do not necessarily have

The appearance, behavior, attitudes and beliefs are included in the literature about the 'Big Five' human personality dimensions. Basic demographic characteristics, such as age, gender and social class, are not included in this literature. A reason for this might be that the basic human demographic characteristics are visible or relatively easily inferred. The demographic characteristics of brands, in contrast, are included in the dimensions of brand personality. The 
reason for the inclusion lies with the fact that the demographics of brands often belong to its most salient personality characteristics (Batra, Lehmann \& Singh, 1993). Unlike with a person, the gender or the age of a brand is not visible or easily inferred. The demographics of a brand are inferred for example from the brand's user imagery.

\section{The creation of brand personality}

Brand personality traits are formed and influenced by any direct or indirect contact that the consumer has with a brand. A brand, unlike a person, cannot think, feel or act. A brand has no objective existence at all; it is simply a collection of perceptions in the mind of the consumer. Consumers accept the marketing actions to humanize brands. One explanation for this can be found in the theories of animism, which suggest that there exists need by people to anthropomorphize objects in order to facilitate interactions with the nonmaterial world (Fournier, 1998). Anthropomorphization occurs when human qualities are attributed to nonhuman objects, e.g. brands. Consumers easily assign personality qualities to inanimate objects like brands in thinking about brands as if they are human characters (Blackston, 1993; Fournier, 1998; J. Aaker, 1997).

In a direct way, personality traits are associated with a brand by the people associated to that brand (J. Aaker, 1997). One direct way to form and influence brand personality is user imagery. User imagery is defined as the set of human characteristics associated with the typical or stereotype user of the brand. Associations with the company's employees or CEO, and the brand's product endorsers are also direct ways by which brand personality traits are formed and influenced. The personality traits of the people associated with a brand are transferred directly to the brand.

The theories of animism describe another process mechanism that directly explains the specific ways in which the vitality of the brand can be realized (Fournier, 1998). Spokespersons that are used in advertising can have personalities that fit those of the brands they advertise. Over time, the personalities of the spokespersons are transmitted to the brand.

The brand-person associations can also have a more personal nature. Brands can be associated with persons who use or used that particular brand, for example a close friend or a family member. Also, brands received as gifts can also be associated with the person from whom the gift was received. These person associations serve to animate the brand as a vital entity in the minds of the consumers. Obviously, this aspect is much less under the control of marketers.

Indirectly, the brand personality is created by all the elements of the marketing mix. Betra, Lehmann and Singh (1993) suggest that the personality of a brand is created over time, by the 
entire marketing mix of the brand - "its price (high or low, odd or even), retail store location (imagery associations), product formulation (ingredients, benefits), product form (solid/liquid, etc.), packaging details (color, size, material, shape), symbol used in all phases of the brand communication, sales promotion, and media advertising" (p. 93).

Another form of animism explains how brand personality is created in a more indirect way. This form of animism involves complete anthropomorphization of the brand object itself. Human qualities of emotionality and thought are transferred to the brand. This is achieved with the help of the marketing actions, especially advertising. For example, the brand character of $M \& M$ in the $M \& M$ commercials has the capacity to laugh and joke.

One of the advantages of brand personalities is that based on their distinctive personalities, consumers are able to differentiate between brands. Another advantage is that the consumer can interpret the brand's image in such a way that it is personally more meaningful. Brand personality encourages more active processing on the part of the consumer. Thus, the consumer puts more effort in creating and using the brand personality.

A further advantage of brand personality is that life is given to a brand. By vitalizing a brand, another perspective of brand personality can be examined, namely the role of a brand as a relationship partner in a consumer-brand relationship. Next we will concentrate on these consumer-brand relationships.

\section{Consumer-brand relationships}

The theories of animism suggest that anthropomorphizing objects facilitates interactions with the nonmaterial world. By assigning human qualities to inanimate products, by giving brands personalities, the vitality of a brand is realized. By vitalizing a brand another perspective of brand personality can be examined, namely the role of a brand as a relationship partner in consumer-brand relationships. A consumer-brand relationship can be compared with an interpersonal relationship, where the brand personality indicates the type of person the brand is.

People have different motives to engage in relationships. The motivation behind the relationships is driven by the needs that individuals want to satisfy. The most used and wellknown classification of needs in Maslow's hierarchy of needs: physiological needs, safety needs, social needs, esteem needs, and self-actualization needs. Fournier (1998) states that 
relationships are "purposive, involving at their core the provision of meaning to the persons who engage them" (p.344).

Three important sources of meaning are identified that explain the significance of the relationship for the person involved; the functional meanings, the psychological/emotional, and the sociocultural meanings (Fournier, 1998).

Consumer- brand relationships provide a practical or functional meaning to the consumer (Franzen \& Bouwman, 1999). In this case the brand is used for its functional benefits. For example, the functional benefit of the pasta brand Barilla is to still the hunger. Over time, using the same brand can become a question of habit and convenience.

The psychological/emotional meanings of a relationship are highly related to the activity around the identity of a person. Because the sense of 'self' grows of reactions of significant others (the relationship partner), people engage in relationships to define the 'self'. Consumers look for brand meanings that help to construct the 'self'. This is most commonly done by brands representing ideal personalities, or alternative reflecting one's own individual identity. Following the same line of reasoning we propose:

Proposition 1: In consumer-brand relationships, consumers search for brands that have personalities that are similar to their own, or personalities that represent the ideal personalities, in psychological/emotional terms

People are constantly constructing and reconstructing their self-identity (McCracken, 1993). In a consumer-brand relationship the consumers choose brands that help the individual reconstruct the 'self', where the brand personality is used to make the identity change. Hence, relationships also help the individual to change the 'self'.

Consumer-brand relationships also help the individual to maintain the self-identity. Consumers will engage in relationships with brands that have similar personalities to their own. A long-term relationship with that particular brand makes sure that the self-identity is maintained.

Consumer-brand relationships also provide a link to the past (Fournier, 1998). A consumer has a relationship with a particular brand, for example because the brand was a present received in the past, or because that brand brings up memories from childhood.

Another type of meaning that consumer-brand relationships provide is sociocultural of nature. There are five broad sociocultural contexts that describe relationship attitudes and behaviors; age/cohort, life cycle, gender, family/social network, and culture (Fournier, 1998). Here, the 
brand personality communicates these sociocultural contexts to the consumer. Related to the sociocultural meanings of the consumer-brand relationships we suggest:

Proposition 2: Consumers engage in relationships with brands that represent their age, stage in life cycle, gender, social network, and culture

Thus, while the psychological/ emotional need is to construct, reconstruct and maintain the self-identity, the sociocultural need is to communicate to others the self-identity.

\section{Types of relationships}

Just like with human relationships, consumer-brand relationships are based on attraction, but the ability of a relationship to endure is a function of investment and commitment by the consumer (Fajer \& Schouten, 1995). The level of investment and commitment in consumerbrand relationships is represented by the level of consumer brand loyalty. Consumer-brand relationships can be ordered based on purchase behavior and their interpersonal analogs, the level of brand loyalty (Fajer \& Schouten, 1995). Accordingly, consumer-brand relationship can range from low-order relationships, where the level of consumer brand loyalty is low, to higher-order relationships, where the level of consumer brand loyalty is high. Hence:

\section{Proposition 3: More investment in consumer-brand relationships leads to greater} loyalty

Information about the type of relationship (based on the level of brand loyalty) consumer have with brands is extremely valuable for marketers. Marketers know the levels of brand loyalty of their target market, and by using their marketing tools they can try to improve the level of brand loyalty for consumers that have low-order relationships with brands.

\section{Advertising and brand personality}

Advertising can help create the brand personality. The semiotic approach provides an understanding how brand personality is created in advertising. From a semiotic perspective, an advertisement may be defined as: "a sign, representing the actual product image (or object), the meaning of which is dependent on the interpretation of the ad recipient (interpretant), which in turn is based on the context in which the ad (sign) occurs" (Dingena, 1994, p.36). See figure 4. 
Figure 4: Brand personality creation and transfer (adapted from Dingena, 1994).

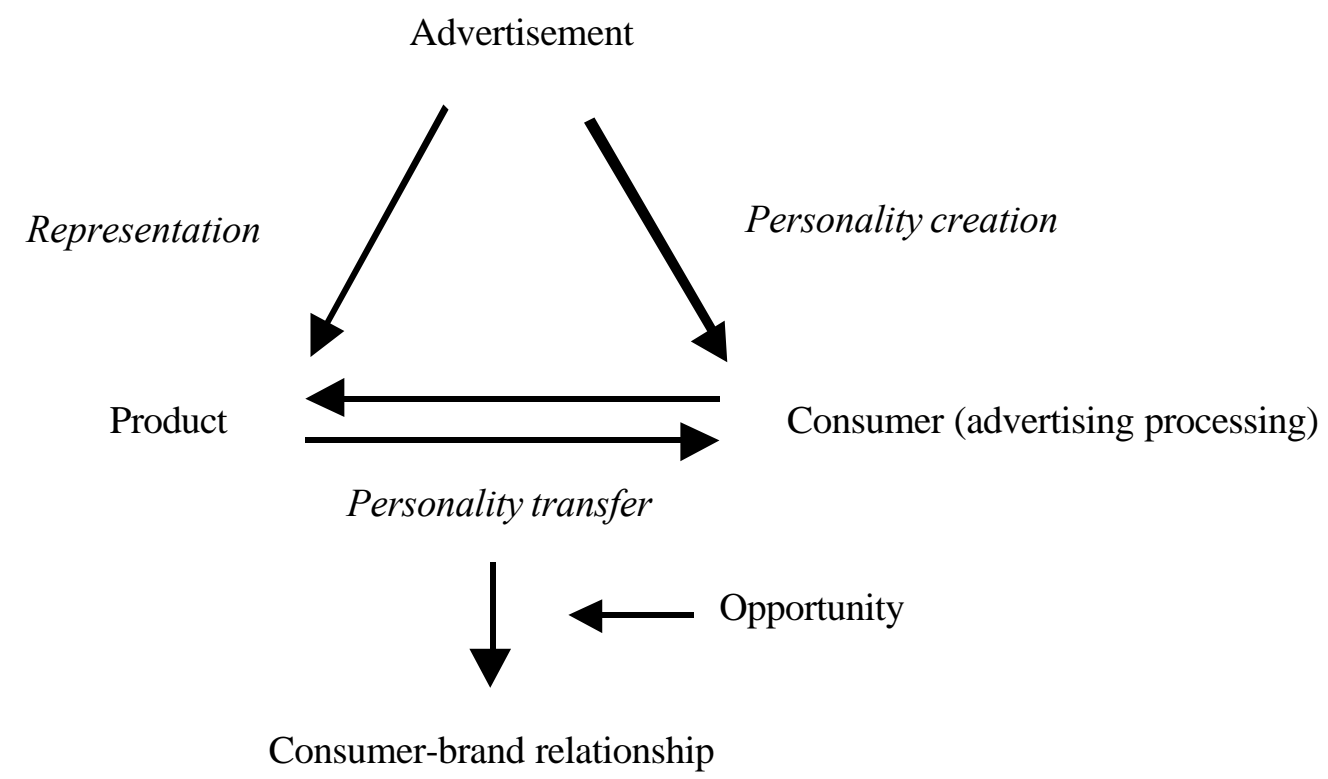

The 'actual product' variable of the model refers to the concrete or actual image of the product (Pieters \& van Raaij, 1992). The concrete image of the product is created through an objective description of the product. According to Dingena (1994), the attributes, benefits and values of the product are also the product's meanings.

The product's meanings are also an important source of brand personality creation in the advertisement. The ad represents the product's meanings, the claimed image of the product. Although the definition of advertising from a semiotic perspective states that the advertisement represents the actual product image, the advertisement represents the product only when there is harmony between the actual and the claimed image of the product (Pieters \& van Raaij, 1992).

If an advertisement represents the actual product, the advertising message contains information about the brand personality that is intended by the advertiser to communicate to consumers. Although the advertiser has created a personality for a brand, it does not imply that consumers will assign that particular personality to the brand. Consumers have to interpret the ad in order to comprehend the personality. After consumers have comprehended the personality, this personality has to be transferred or connected to the advertised product and the consumer. 
Brand personality can be created trough advertising in a direct as well as in an indirect way. In a direct way, the brand personality is created by tansferring the personality of a person used in the ad. In an indirect way, the brand personality is derived from the product's meanings. For example, if the benefit of a brand is 'success', the personality of that brand can be 'successful' and/or 'confident'.

For a brand personality to be created in the minds of consumers, it first has to be connected to the advertised product. The brand personality is not received from the ad, the consumer has to create the personality. In other words, the transfer of he brand personality is not completed within the ad, the viewer has to make the connection between the brand personality communicated in the ad and the advertised product. The consumer has to connect the personality of the person in the ad, and/or the personality derived from the meanings of the product to the advertised product. By doing this consumers humanize brand and give them human personalities. Thus:

Proposition 4: The brand personality creation of the advertised product requires that consumers link the inferred human qualities to that advertised product

Consumers will utilize this created brand personality only when they also connect it to themselves. The personality of the brand will only be connected to the consumer if he/she perceives the personality as important. This will at least occur when the brand personality is similar to their own, or when the personality represents the ideal personality. Thus:

Proposition 5: The brand personality transfer to the 'self' occurs when there is a match between the personality of the advertised product and the own or ideal personality

After consumers have humanized brands, they can engage in relationships with them (see figure 4). A consumer-brand relationship is realized when the consumer actually purchases the advertised product. This will not happen automatically, but requires an opportunity to take place. Opportunity refers to, for example the absence of monetary restrictions, or the physical availability of the brand.

Proposition 6: A consumer-brand relationship is established when the brand personality transfer is followed by a purchase 
The creation and transfer of the brand personality is dependent on the way consumers process the advertisement. For a thorough understanding of advertising processing, and consequently the creation and transfer of brand personality through advertising, one should also look at the way advertising works. There are different models that explain how advertising works. Most of these models follow the same line of reasoning, namely that there is input in the model, transformation, and output. The input of the model refers to the advertising exposure, transformation refers to adverting processing, and output refers to advertising responses. In figure 5 the creation and transfer of brand personality is represented in the model of how advertising works.

Figure 5: Model of how advertising works including the brand personality creation and transfer

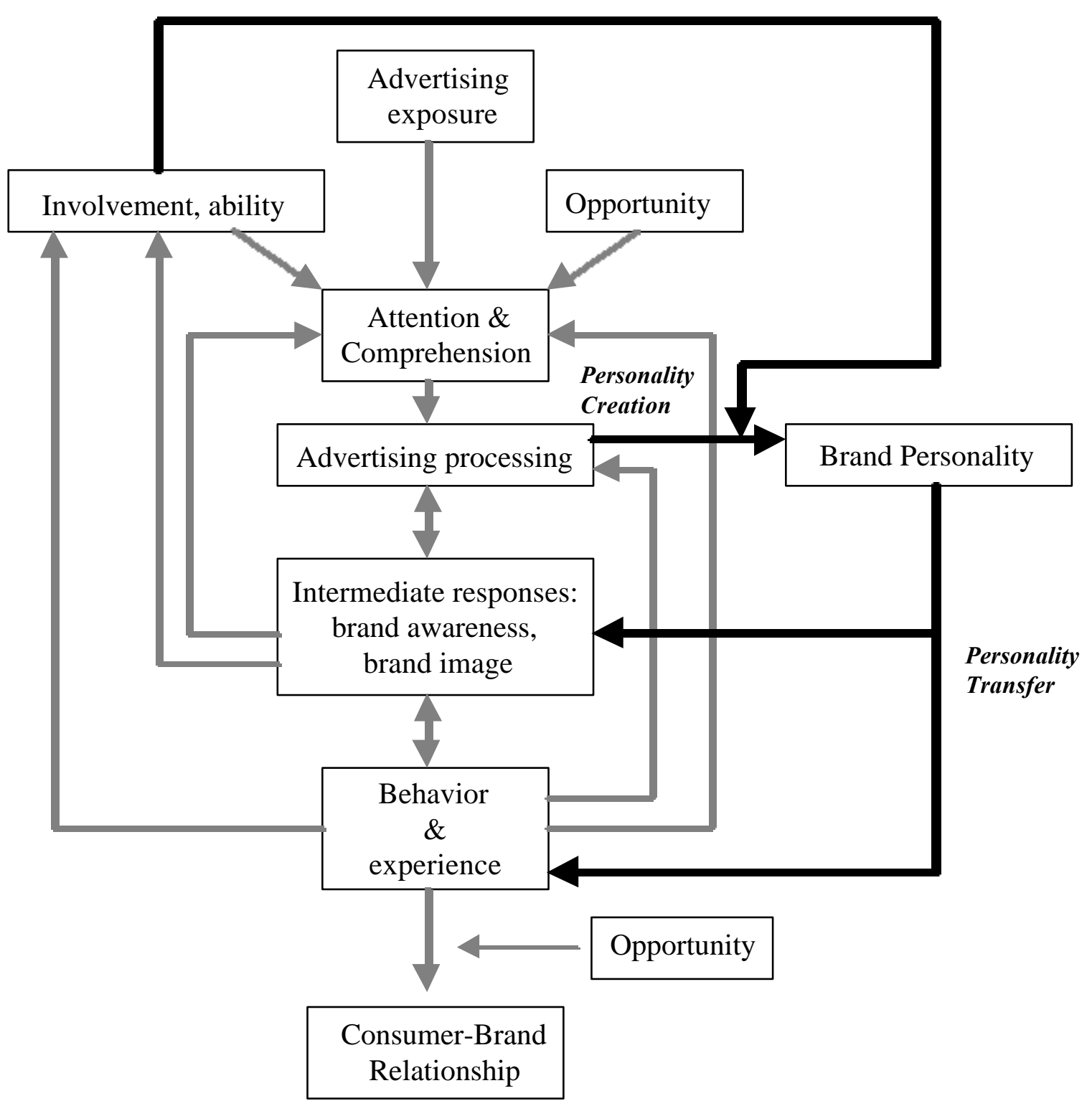




\section{Advertising exposure}

The advertising exposure involves decisions that advertisers make before consumers can be exposed to the advertisements. These decisions involve media choice and media scheduling (Wells, Burnett \& Moriarty, 1998) as well as the communication style -literal or figurative (Dingena, 1994)- , the communication mode - pictorial or verbal (Dingena, 1994)-, and the message content - informational or transformational (Pieters \& van Raaij, 1992; Swaminathan, Zinkhan \& Reddy, 1996; Dingena, 1994). Advertisers use the message content, as well as the communication style and mode to communicate the product's meanings, and thus the determined brand personality to consumers. Whether this determined personality will be decoded, is depended on advertising processing.

\section{Advertising processing}

When confronted with the advertising exposure, consumers will process the advertising stimuli. The way people process advertising differs. Some people only watch the advertisement without activating their brain, others try to understand the information offered in the ad, they structure the information to fit in their existing knowledge structures (Vakratsas \& Ambler, 1999).

Brand personality creation and transfer depends on the way consumers process advertising. The advertiser may want to communicate a certain personality to the consumer, but how the personality will be interpreted is dependent on the way the consumer will process the ad. Thus,

Proposition 7: Brand personality is created by consumers during advertising processing

The way consumers process advertisements, and consequently create the brand personality, is dependent on how the cognitive and affective systems are activated while exposed to the ad.

A lot of research has been done related to the role of cognition and affect on advertising processing and response. This has resulted in different advertising processing theories where cognition and affect play different roles. These theories include cognitive processing theories that assume that an advertisement will only be processed by the cognitive system, pure affect processing theories, which pay no or little attention to cognition, and theories that include both the cognitive and affective system in the process of advertising (Vakratsas \& Ambler, 1999). 
Franzen (1992), and Pieters and van Raaij (1992) argue that cognition and affect influence each other, and consequently can be seen as two components of one system. The underlying idea is that thoughts are not free of feelings and vice versa. Thus, advertising processing and response are a combination of both cognition and affect. Consumers use both their cognitive and affective system to process advertising, and advertising responses can be both cognitive and affective. For example, an ad with a more informational message should activate the cognitive system, but the ad can also affect the affective system, the ad can be perceived as boring. Also, ads that involve a more emotional content can also activate the cognitive system.

Franzen (1992) argues that in advertising processing the sequence of cognition and affect is not important. Both impact on the consumer's attitude and behavior and the level of this impact does not depend on the order of the processes. Franzen's argument seems plausible in the context of one-shot processing of advertising experiences. In the case of advertising campaigns, with multiple and different messages the order effects may be important (Van Osselaer \& Alba, 2000). In particular since companies have full discretion in designing campaigns, it is all the more interesting to see if it makes a difference whether you start building brand personality by appealing to affective or cognitive reactions.

But even in case of one-shot advertisements this order can be important. The design of advertisements can be used to attract attention first to either affective or to cognitive stimuli. Consequently, also in an attentional (in contrast to the temporal dimension described above) sense order effects are worth investigating. So we formulate the following:

Proposition 8: The order in which affective and cognitive stimuli are processed influences the creation of brand personality

This influence can be formulated in different ways. First, the outcomes of the processes may be different. Alternatively, the effectiveness of the processes may differ. Further we may look for contingencies that moderate this influence. For example, high involvement products require much more attention in the information search stages of the buying process. Consequently, for search products, cognitive stimuli may be more important than affective stimuli, and therefore, when those cognitive stimuli are provided first, the affective stimuli that are processed later might be more effective. So, there are many variations with respect to the influence of the order of stimuli that are interesting to investigate. 


\section{Advertising responses}

The ultimate response that advertisers want to achieve through advertisements is consumer behavior. Advertisers want consumers to choose, purchase, consume the advertised brand, and become loyal to it. But before advertising moves people to behave toward the brand, it first has to lead to intermediate responses (Franzen, 1992; Pieters \& van Raaij, 1992; Dingena, 1994; Vakratsas \& Ambler, 1999). The intermediate responses are related to the brand knowledge. One intermediate response is brand awareness, consumers have to become aware of the brand's existence before they can decide to purchase it. Another intermediate response to advertising is formed by brand associations. The advertising processing directly influences the intermediate responses, and indirectly (through the intermediate responses) the consumer behavior.

Most of the times there are already existing associations related to the advertised brand. Sometimes the consumer is aware of the advertised brand, and he/she may even have an image about the brand. When this occurs, this brand knowledge will influence the way consumers will process the advertisement. Also, some consumers will also have experience with the brand. This brand experience will influence the brand knowledge, which in turn will influence the advertising processing. Thus, advertising processing does not only directly and indirectly influence the intermediate responses and brand behavior and experience respectively, it is also directly and indirectly influenced by the intermediate responses and brand behavior and experience respectively.

From the brand personality point of view, the intermediate responses, as well as behavior and experience are related to the creation and transfer of brand personality. Looking at the fact that the intermediate responses of advertising directly influence advertising processing we suggest that the intermediate responses also play a role in the creation of brand personality. The creation of brand personality occurs during advertising processing, which is directly influenced by the intermediate responses as well as brand behavior and experience. Consequently we formulated the following propositions:

Proposition 9: The intermediate responses of advertising (brand knowledge) indirectly influence the creation of brand personality through advertising

Proposition 10: Brand behavior and experience indirectly influence the creation of brand personality 
Before the brand personality can be utilized by consumers, it first has to be connected to the advertised product (see figure 4). The transfer of the brand personality to the advertised product is completed when the brand personality becomes a component of the brand image. Thus:

Proposition 11: The brand personality creation of the advertised product directly influences the brand knowledge (intermediate response), especially the brand image

After the brand personality has been connected to the advertised product, the brand personality will be connected to the consumer. When this connection is established, consumers will utilize the brand personality for the achievement of personal needs, by the act of buying the advertised product. Thus:

Proposition 12: The brand personality transfer to the 'self' directly influences the brand behavior and experience

\section{Mediating factors of advertising processing}

Advertising processing is mediated by several factors which have to be mentioned in order to understand the process of how advertising works. These factors are attention and comprehension, brand knowledge, and brand behavior and experience.

\section{Attention and comprehension}

Attention and comprehension is essential for advertising processing. Attention is the process that leads to the concentration of the mental energy on a stimulus (Franzen, 1992). Attention is a situation where the consumer's brain interacts with the advertising stimuli. For example, persons who are interested in automobiles will pay more attention to advertisements that involve automobiles. Ad stimuli are stimuli that are related to the communication style (literal vs. figurative), mode (pictorial vs. verbal), and message content (informational vs. transformational) of the ad.

Comprehension refers to the level of knowledge and meanings activated by consumers resulting from being exposed to the advertisement (Pieters \& van Raaij, 1992). Mick (1992) distinguishes two orientations toward message comprehension namely, objective and subjective comprehension. Objective comprehension is conceptualized as " the grasping or extracting of pre-specifiable meanings form the message (Mick, 1992, p.411). The meanings and personality of the ad are considered as given and intended by the advertiser. On the other hand, subjective comprehension is conceptualized as " the generation of meanings by a 
particular individual through the activation of mental concepts related to the message and the processing context, irrespective of whether the generated meanings were intended by the advertiser or contained in the message" (Mick, 1992, p.412). Most of the time, advertisements can be interpreted in different ways by consumers. Although the advertiser has intended meanings and a brand personality that he wants to convey to the consumer, consumers can think, associate, and conclude what they want when exposed to the ad.

The attention given to an ad and the comprehensibility of a message is a function of involvement, ability, and opportunity (Ratneshwar \& Chaiken, 1991; Mick, 1992; Pieters \& van Raaij, 1992; Celsi \& Olson, 1988). Involvement, ability, and opportunity are not only related to attention and comprehension, but also to the intermediate responses of advertising and to brand behavior and experience.

Involvement refers to "the intensity of the consumer's interest in a product, medium, or message" (Wells, Burnett \& Moriarty, 1998, p.253). Involvement is conceptualized in terms of an individual's motivation to process the information stimuli (Peltier \& Schibrowsky, 1994). Motivation on its turn is driven by the need of the consumer that he wants to satisfy in order to achieve certain goals. Thus, if the advertised product can satisfy certain consumer needs, consumers are motivated to process the advertising stimuli, and as a result will be more involved.

According to Pieters \& van Raaij (1992) involvement also refers to the strength of the relationship that consumers already have with brands. Involvement leads to attention, and when people are involved with a product, they will give more attention to the advertising stimuli.

Besides motivation, brand knowledge and experience also influence involvement (Franzen, 1992). Most of the time, the consumer's mind already contains conscious and unconscious memories of product purchasing and usage. According to the associative network memory model, when confronted with the advertising input, knowledge related with the product is retrieved form memory. The strength of the associations will determine what information will be activated. When relevant and important information is retrieved from memory, a higher level of involvement will occur.

Personal goals are also the driving force for consumers to give brands personalities. Consumers create brand personalities to achieve their goals with the help of brands. 
Consumers that are motivated to satisfy certain personal goals will be more involved. The creation of brand personality is also affected by the existing brand knowledge and experience. The information about the brand that is already stored in the memory will help consumers create the brand personality. Therefore, we suggest:

Proposition 13: Involvement directly influences the creation of brand personality (through personal goals) as well as indirectly (through brand knowledge and experience)

Another mediator is ability. The ability to process the advertising input is influenced by the brand knowledge stored in the associative network (Franzen, 1992). The knowledge stored in memory helps consumers to comprehend and process the information form advertisements. Besides brand knowledge, the level of intelligence, general knowledge and experience also influence the ability to process information (Franzen, 1992). According to the associative network memory model, brand knowledge and general knowledge is stored in consumer's minds. Consumers will use this knowledge to create brand personalities. Accordingly we propose:

Proposition 14: Ability directly influences the creation of brand personality (through the level of intelligence and general knowledge) as well as indirectly (through the brand knowledge and experience)

Opportunity refers to "the extent to which external factors like distraction and limited exposure time affect the recipient's ability to attend to and process the information of the ad" (Dingena, 1994, p.71). Opportunity influences the level of attention given to an ad. For instance when consumers have the opportunity to process the advertising stimuli, they will give more attention to the ad. Ratneshwar \& Chaiken (1991) found that opportunity also mediates comprehension. When consumers have the opportunity to process the ad, chances are higher that they will comprehend the message of the ad. Related to brand personality we propose:

Proposition 15: Opportunity indirectly influences the creation of brand personality

\section{Conclusion}

In this paper we integrated an extensive advertising model with a model of brand personality creation. A number of researchable propositions were derived. Research in this area strongly recommended. 
The managerial importance of the topic seems evident. Advertising is by far the most important communication tool in marketing, and with every advertisement brand personality is built. Understanding how brand personality is created in the minds of consumers is essential for effective use of a company's marketing tools. Effective brand management, encompassing brand personality, is of paramount importance in reaching the overall company goals of satisfaction, loyalty, and profitability.

Brand personality is an important, yet largely neglected area in brand management research. Brand management as such has proven its importance and significance. Consequently, we hope to have put brand personality on the research agenda according to the lines set out here. 


\section{References}

Aaker, D. \& Biel, A. (1993). Brand equity \& advertising: advertising's role in building strong brands. Hillsdale: Lawrence Erlbaum Associates Publishers.

Aaker, D. (1991). Managing brand equity. New York: The Free Press.

Aaker, D., (1996). Building strong brands. New York: The Free Press.

Aaker, J. (1997, August). Dimensions of brand personality. Journal of Marketing Research, Vol. 34, pp. 347-356.

Anderson, P. M. \& Rubin, L.G. (1986). Marketing communications: advertising, sales promotion, public relations, display, and personal selling. Englewood Cliffs, New Jersey: Prentice-Hall.

Batra, R., Lehmann, D. \& Singh, D. (1993). The brand personality component of brand goodwill: some antecedents and consequences. In Aaker \& Biel, Brand equity \& advertising: advertising's role in building strong brands (pp. 83-95). Hillsdale: Lawrence Erlbaum Associates Publishers.

Biel, A. (1993). Converting image into equity. In Aaker \& Biel, Brand equity \& advertising: advertising's role in building strong brands (pp. 67-82). Hillsdale: Lawrence Erlbaum Associates Publishers.

Blackston, M. (1993). Beyond brand personality: building brand relationships. In Aaker \& Biel, Brand equity \& advertising: advertising's role in building strong brands (pp. 113-124). Hillsdale: Lawrence Erlbaum Associates Publishers.

Brassington, F. \& Pettitt, S. (2000). Principles of marketing ( $2^{\text {nd }}$ ed.). Harlow: Prentice Hall.

Celsi, R. \& Olson, J. (1988). The role of involvement in attention and comprehension processes. Journal of Consumer Research, Vol. 15, pp.210-224.

Corporate Communication. (1991). Houten: Bohn Stafleu van Loghum.

Dibb, S.; Simkin, L.; Pride, W. \& Ferrell, O. (2001). Marketing: Concepts and strategies $\left(4^{\text {th }}\right.$ ed.). Boston: Houghton Mifflin.

Dingena, M. (1994). The creation of meaning in advertising: Interaction of figurative advertising and individual differences in processing styles. Amsterdam: Thesis Publishers.

Erdogan, Z. \& Baker, M. (2000). Celebrity endorsement: advertising agency managers' perspective. The Cyber-Journal of Sport Marketing (pp.1-15). Retrieved December 11, 2000: http://www.cjsm.com/Vol3/erdogan\&baker33.htm.

Fajer, M. \& Schouten, J. (1995). Breakdown and dissolution of person-brand relationships. Advances in Consumer Research, Vol. 22, pp.663-667.

Fournie.r S. (1998, March). Consumers and their brands: developing relationship theory in consumer researc. Journal of Consumer Research, Vol. 24, pp. 343-370.

Franzen, G. \& Bouwman M. (1999). De mentale wereld van merken. Alphen aan den Rijn: Samsom.

Franzen, G. (1992). Hoe reclame echt werkt. Deventer: Kluwer Bedrijfswetenschappen.

Guilford, J. (1973). On personality. In Mischel, W. Introduction to personality (pp. 22-23).

New York: Holt, Rinehart \& Winston.

Holzhauer, F. (1991). Corporate image en brand image: wat merkartikelreklame doet voor het corporate image. In Corporate Communication (pp. 1-6-1 - 1-6-44). Houten: Bohn Stafleu van Loghum.

Kapferer, J-N. (1997). Strategic brand management (2 ${ }^{\text {nd }}$ ed.). London: Kogan Page.

Keller, K. (1998). Strategic brand management: building, measuring, and managing brand equity. New Jersey: Prentice-Hall.

Kotler, P. \& Armstrong, G. (2001). Principles of marketing ( $9^{\text {th }}$ ed.). New Jersey: PrenticeHall Inc. 
McCracken, G. (1993). The value of the brand: an anthropological perspective. In Aaker \& Biel, Brand equity \& advertising: advertising's role in building strong brands (pp.125-139). Hillsdale: Lawrence Erlbaum Associates Publishers.

Mick, D. (1992, March). Levels of subjective comprehension in advertising processing and their relations to ad perceptions, attitudes, and memory. Journal of Consumer Research, Vol. 18, pp.411-424.

Peltier, J. \& Schibrowsky, J. (1994). Need for cognition, advertising viewing time and memory for advertising stimuli. Advances in Consumer Research, Vol.21, pp. 244-250.

Perreault, W. Jr., \& McCarthy, E. (1999). Basic Marketing: a global-managerial approach. Boston: Irwin McGraw-Hill.

Pieters, R. \& van Raaij, F. (1992). Reclame Werking. Leiden/Antwerpen: Stenfert Kroese.

Poiesz, T. (1989). The image concept: it's place in consumer psychology. Journal of Economic Psychology, Vol. 10, pp. 457-472.

Ratneshwar, S. \& Chaiken, S. (1991). Comprehension's role in persuasion: The case of its moderating effect on the persuasive impact of source cues. Journal of Consumer Research, Vol. 18, pp. 52-62.

Redenbach, A. (2000). A multiple product endorser can be a credible source. The CyberJournal of Sport Marketing (pp.1-10). Retrieved December 11, 2000: http://www.cjsm.com/Vol3/redenbach31.htm.

Swaminathan, V., Zinkhan, G. \& Reddy, S. (1996). The evolution and antecedents of transformational advertising: a conceptual model. Advances in Consumer Research, Vol. 23, pp. 49-55.

Vakratsas, D. \& Ambler, T. (1999, January). How advertising works: what do we really know?. Journal of Marketing, Vol. 63, pp.26-43.

Van Osselaer, S. \& Alba, J. (2000, June). Consumer learning and brand equity. Journal of Consumer Research, Vol. 27, pp. 1-16.

Wells, W., Burnett, J., \& Moriarty, S. (1998). Advertising: principles \& practice (4 ${ }^{\text {th }}$ ed.). New Jersey: Prentice-Hall. 